Party Positions about European Integration in Germany: An Electoral Quandary?

\author{
Robert Rohrschneider \\ corresponding author) \\ Department of Political Science \\ The University of Kansas \\ Lawrence, KS 66045 \\ USA \\ roro@ku.edu
}

\author{
Stephen Whitefield \\ Department of Political and International Relations and Pembroke College \\ Oxford University \\ Oxford OX1 1DW \\ UK \\ stephen.whitefield@politics.ox.ac.uk
}

\title{
6772 Words
}

Key words: party positions; European integration; german politics; 2013 federal elections.

Abstract.

Given the rise of EU skepticism in Germany and elsewhere, spatial models suggest that the SPD and CDU/CSU have incentives to move towards a more critical position about integration. However, mainstream parties have developed a pro-integration reputation over several decades so it difficult for them to adopt a stance reflecting outright opposition to Europe's integration. A comparison of party positions in 2008 and 2013 shows that the SPD hardly changed its policy stances on EU issues, whereas the CDU/CSU moved noticeably to a more EU-critical stance. However, situating German parties within the West European universe of party families shows that both remain quite positive about integration. The upshot of this is to illustrate the "blind corner" of party representation on integration issues in the German party system which created electoral opportunities for the Euro-skeptic AfD. 


\section{Introduction}

Does the EU's economic crisis prompt mainstream parties in Germany to appeal to EU-skeptical voters? It would appear that Europe's crisis provides especially the SPD and CDU/CSU with incentives to become more critical about the EU. Public opinion in Germany (and elsewhere) has clearly shifted towards a more critical view about Europe's integration as financial rescue policies may substantially drain Germany's resources if a troubled country defaults on her debt, the EU's effectiveness as a competent actor is being undermined, and national resentment against the perceived profligacy of governments in crisis countries generated a backlash against further financial support Therefore, we ask: to what extend have mainstream parties modified their programs about European integration? Have they moved with the German public towards a more EU-critical stance? Or is the articulation of an EU-skeptical position in the German party system left to Die Linke and the newly formed Alternative for Germany (AfD)? A first goal is to describe the programmatic stances of Germany's party system on European integration between 2008 and 2013 on the basis of two expert surveys.

Theoretically, we are motivated to examine parties' programmatic behavior about European integration on the basis of two conflicting perspectives. First, spatial models suggest that political parties have incentives to move where voters position themselves programmatically. If this is the case, then mainstream parties in Germany (and elsewhere) have clear incentives to become more EU-skeptical. ${ }^{1}$ The near-entry of the AfD into the Bundestag in 2013 highlights the resentment many voters harbor against the way that the EU structured financial bailout packages. Moreover, its rise means that criticisms of the EU at the party-level are articulated in public debates not just by individual party members within the established parties (as occurred within the CDU and the FDP) but now can vote for a party that is devoted to achieve an exit from the Euro. 
Another set of incentives, however, follows from the historically grown reputation of mainstream parties as unwavering promoters of Europe's integration, as well as their issue ownership on domestic cleavages. Reputationally, parties face clear incentives to remain supportive of the EU given that they were instrumental in creating the "permissive consensus"-a ubiquitous agreement that integration is desirable-which provided the support required to develop Europe's integrated market up to the 1970s and, more recently and precariously, to advance Europe's ambitious attempt to unify the continent politically. ${ }^{2}$ Since the SPD or the CDU/CSU have been part of every government since 1949 , it is difficult for them to run away from their historically grown pro-EU stance. ${ }^{3} \mathrm{As}$ a consequence, major parties have good reasons to stay programmatically on a pro-integration position because they promoted the "ever closer union" of Europe during much of the postwar era. In addition, mainstream parties have incentives to compete on familiar divisions (primarily economic) and eschew conflicts where they may be internally divided, like integration. Thus, in contrast to the spatial mechanisms, reputational imperatives predict that the SPD and the CDU/CSU maintain their support for Europe's integration several years into the crisis.

On the basis of the German case and using two expert surveys conducted in Germany (and elsewhere) in the spring of 2008 and $2013^{4}$-we will shed light on which of these conflicting mechanisms more aptly describes the programmatic position of Germany's parties on European integration. The results show that the SPD continues to support integration as does the CDU/CSU, though we will also see show that the CDU/CSU has moved a bit more towards a more muted support for integration over time, presumably in response to the rise of the AfD. Still, in comparison to other Christian Democrats in Western Europe, our analyses show that the Union remains steadfastly supportive of the EU. We recognize that a two-wave panel survey of party positions generates limited evidence of how much party positions change over time and we therefore do not wish to overstate our results. We would argue, however, that two reasons support our argument that the findings are of 
theoretical significance. First, the substantial drop in support for Europe's integration among the German public (see table 1) provides parties with clear incentives to respond to these opinion movements. The permissive consensus that undergirded Europe's integration has clearly given way to a "restrained dissent" ${ }^{1}$ which means that political integration is considerably more controversial than economic integration has ever been. If parties choose not to address the shift in public opinion, it does point to the potential for underrepresentation of voters' preferences on this salient political issue. Second, as our analyses will show, one party-the CSU-has begun to cautiously respond to these pressures and, moreover, other parties of the Christian Democratic party family in Europe also move noticeably towards an EU-skeptical position. There is therefore nothing "natural" about the lack of respond among Germany's mainstream parties we find in our study-parties have a choice and, in most cases, they opted for stasis.

To explain how we arrived at these conclusions, we will first discuss the potential pressures parties face over integration, and how spatial and reputational Considerations capture the crosspressures that parties face. We will then use two expert surveys conducted at the beginning of the crisis in $2007 / 2008$ and again in 2013 to study party positions on integration over time. A third section will assess the degree to which parties in Germany follow the general European patterns across party families.

\footnotetext{
${ }^{1}$ Liesbet Hooghe and Gary Marks. 2008. "A Postfunctionalist Theory of European Integration: From Permissive Consensus to Cosntraining Dissensus." British Journal of Political Science (39): 1-23.
} 


\section{How do the SPD and CDU/CSU respond to Europe's Crisis? Spatial and Reputational}

\section{Considerations}

Since the onset of the greatest economic crisis around 2007, German governments have faced a series of challenges. Initially, governing parties (up to 2009 a Grand Coalition of the SPD and CDU/CSU) had to support German banks and some companies (e.g., GM's subsidiary Opel) which experienced serious financial problems in the wake of the Lehman flop, the fallout from the near-collapse of the US banking system, and questionable investments made by German banks. Germany's economy weathered these events comparatively well, in part because of its booming export sector, in part because of the labor market reforms undertaken a decade earlier, whereas other national sovereigns which had become deeply entwined with their financial sectors, suffered dearly, especially in Greece, Ireland, Portugal, and Spain. In short, the economic crisis never fully arrived in Germany, certainly not at the level of citizens who continued to experience a booming economy, low inflation and unemployment rates (see the introduction to this special issue).

However, despite the positive economic conditions in Germany-conditions which typically generate support for European integration among mass publics ${ }^{5}$-skepticism began to form among the German public. It developed because growing debates over the soundness of financial rescue packages for troubled economies raised the salience of economic issues among voters. While the crises did not require the German taxpayer to transfer significant resources right away, the German treasury committed substantial sums to the European Stability Mechanism (ESM for short) which was designed as a "firewall" to secure the financial liquidity of European governments from fiscal upheavals. ${ }^{6}$ Controversies also arose because of the perceived profligacy of especially the Greek government to live beyond its means (e.g., early retirement options), its presumed inefficiency (e.g., does not collect taxes effectively), and a perception of significant corruption. As a result, public opinion in Germany lowered its support for the EU in the wake of these debates which were not only covered extensively in the mass 
media but also obtained a focal point through the newly founded AfD which advocates Germany's withdrawal from the Euro.

Table 1 suggests that there is indeed a decline in support for variously phrased integration measures. Although the drop does not reach the levels in Southern Europe-in Greece, for example, public evaluations of whether Greece's membership was a good thing declined from 76 percent in 2009 to 43 percent in 2014-it is also noticeable in Germany. What is more, it emerges with different indicators. The membership indicator continues to show clear support for the EU when roughly two thirds of the German public respond that Germany's EU membership has been good-but this indicator focuses more on the past than the current events. The second indicator-on the pace of reform-shows a bit more ambivalence when only one third indicate that integration should go further, down from nearly 44 percent in 2009 . Note that the 2009 baseline already reflects some of the decline that took place before then ${ }^{7}$-so these estimates in weaker public support are conservative. In a word, national interests-above all economic and fiscal ones-became more salient and began to undermine Germany's traditionally strong support for Europe's integration. ${ }^{8}$

Table 1 about here

Given this backdrop, spatial models suggest that parties have incentives to become more EUskeptical. If voters become more critical about integration, then parties which have historically supported the integration project-especially the SPD and CDU/CSU-have incentives to mute their support for European integration in order to attract voters who are dissatisfied with the current EU policies. ${ }^{2}$ What is more, Social Democrats may increasingly be unhappy with the content of financial rescue packages which often require austerity measures that lower the standard of living of many ordinary citizens in crisis-plagued nations which conflicts with a "social vision" of Europe that Social

\footnotetext{
${ }^{2}$ This discussion relies on the theoretical account developed in Robert Rohrschneider and Stephen Whitefield. 2016. "Responding to growing European Union-skepticism? The stances of political parties toward European integration in Western and Eastern Europe following the financial crisis." European Union Politics 17(1): 138-161.
} 
Democrats subscribe to. ${ }^{9}$ In turn, the CDU and, especially the CSU may well be dissatisfied with the way that national sovereignty is lowered as a result of the way that top-level meetings in Brussels (and elsewhere) determine the fate not only of countries-in-need but also reduce Germany's sovereign ability to spend its resources as it sees fit. Thus, on the basis of spatial incentives the way the economic crisis unfolded leads to the following hypothesis:

Hypothesis 1: By 2013, the SPD and CDU/CSU moved to a (moderate) criticism of Europe's market and political integration.

Reputationally, however, the historical commitment of German mainstream parties conflicts with the incentives to become more EU-skeptical. From Germany's vantage point, Europe's integration was historically seen as a way to resuscitate Germany from the ashes of World War II; a memory that motivated Union and SPD-led governments to push the development of the single European market from Adenauer and Kiesinger (CDU) up to the 1960s, Brandt and Schmidt (SPD) throughout the 1970s, to Kohl (CDU) up to the 1990 s. ${ }^{10}$ All mainstream parties, in short, helped to develop the European project and thus have developed a reputation as staunch supporters of integration. Given this policy reputation, and the fact that both the SPD and the CDU/CSU designed the financial rescue packages over the past five years, German voters typically view mainstream parties as supporters of the EU. Because a reputation cannot be easily changed without running the serious risk of appearing implausible to voters, it is difficult now for the mainstream parties to "run away" from their historic support for Europe's integration. ${ }^{11}$ In short, the reputational argument suggests that the SPD and CDU/CSU remain largely supportive of Europe's integration.

In contrast, the main critics of the EU should be found at both the right and left extreme of Germany's party system. The left has historically sided with the underdog and continues to be the champion of economically weak citizens both at home and internationally. ${ }^{12}$ This strategy works well for Die Linke because extreme parties have incentives to use a wedge issue like integration, which does not 
fit well with domestic party positions, to unsettle established party-voter alliances..$^{13}$ In turn, the AfD is a newly founded party with the explicit aim to withdraw from the Euro. ${ }^{14}$ Both mainstream parties thus face a credible threat on the integration dimension on their left and right flanks. Any attempt to usurp an EU-skeptical position by the SPD and the CDU/CSU thus runs the risk of being viewed as the "copy" which may just serve to raise the salience of EU-skepticism and in the end might prompt voters to support Die Linke or the AfD as the "original" provider of an EU-skeptical stance. Therefore, the reputational perspective hypothesizes:

Hypothesis 2: Mainstream parties have remained positive about integration; EU-skepticism is mainly found among Die Linke and the AfD.

The following analyses will test the two hypotheses.

\section{Party Positions on European Integration during the 2013 Federal Election Campaign}

How did the parties respond to the crisis since 2008? To begin with, we examine the importance of integration issues during the 2013 election campaign. Generally, the political divisions in Germany follow the well-known narrative that the CDU/CSU, FDP, and SPD constituted the bulwark of Germany's party democracy until about the mid-1970s. ${ }^{15}$ The Social Democrats have typically attracted working and lower middle class voters, along with secular voters, whereas the CDU/CSU appealed mostly to the middle and upper class voters, in addition to religiously motivated voters. ${ }^{16}$ The FDP, meanwhile, restricts its appeal to higher income voters. From the mid-1970s onwards, changes in the party system led to the rise of the Green party and, after Germany's unification, the current version of Die Linke party. While unification temporarily unsettled historically grown party-voter alliances, the German party system nowadays approximate the partisan patterns one observes historically. ${ }^{17}$ At the center left, three parties vie for left-leaning voters-Die Linke, Die Grünen, and the SPD; at the center-right, we see mainly the CDU/CSU and the presently almost-defunct liberals (FDP). Historically, the main divisions 
have been over domestic issues and, increasingly, cultural issues such as environmentalism, gender equality, and migration, whereas integration played a second fiddle, if that at all and, moreover, does not neatly align with party positions on domestic stances. ${ }^{18}$

Given this backdrop, and the economic malaise, how important is Europe's integration as a basis for party competition in Germany during 2013? As part of a comprehensive assessment of party stances in Europe, we conducted an expert survey in Germany in the spring of 2008 and again in the spring and summer 2013, about five years after the economic crisis began to unfold-and a few months before the 2013 election campaign took place. ${ }^{19}$

To begin with, we asked our experts to identify the most salient political divisions that divide parties:

"We would like to begin by asking about the party system as a whole. Some countries may have multiple issue dimensions structuring party competition, others only one, and some of course may have none at all. Could you please indicate how important each issue dimension is in the party system of [country]? If two issue dimensions are about equally important, please still rank order them for the purpose of the next question."

We showed experts a card that contained several potential divisions (see the appendix for a complete list). There is a clear consensus that domestic, re-distributional issues top the list (table 2). This is the case in 2008 and, again, in 2013. A bit surprising in light of the economic malaise is that the second most important issues continue to be cultural issues - over gay rights, gender equality, migration, and environmentalism - which end up near the top in in 2008 and in 2013. Even though the economic crisis gripped Europe during this time, and much of the party elites in Germany debated financial bailout packages, domestic cultural issues still trump international ones according to our experts. Clearly, one reason is that Germany's unemployment rate remains at low levels, hovering around 6-7 percent at the time of the surveys; growth is noticeable, inflation rates remain acceptably low, and the federal budget is balanced. Only when we look at the third place, do we see international issues surface in 2013. While 
this slight increase in importance no doubt is due to the enormous difficulties the economic crisis produced in Europe, we interpret the overall ranking as a sign of Germany's economic strength. In the end, EU issues do not trump the two domestic conflict dimensions that shaped much of post-war Germany-a situation which reflects the resilience of the German economy.

Table 2 about here

What are the positions of Germany's parties on European integration five years into the economic crisis? We asked four questions in our expert survey, beginning with a general indicator of their orientation towards integration:

"How about the EU? Regardless of the specific form that integration may take, where do parties stand on creating a politically unified Europe? Do they strongly support a politically unified Europe (in which case they would score 7) or do they strongly oppose a politically unified Europe (in which case they would score 1) or something in between?"

We also asked them to indicate where parties stand on market integration:

"Where do the parties in [country] stand on creating a Europe-wide, integrated market for the European Union?"

Finally, a nearly identical question taps whether parties support Europe's political integration (see the appendix). We created an additive indicator based on these three questions given its high correlations where 3 expresses complete opposition to the EU and 21 expresses complete support. ${ }^{20}$ We also asked how parties evaluate the current performance of the EU:

"And what about the party's view of how well democracy works in the EU?" 1 denotes "Does not work at all" and 7 denotes "Works very well."

We kept the performance indicator separate from the principles indicator because it measures the actual operating procedures of the EU which is conceptually distinct. It is conceivable that parties support the idea of integration while being dissatisfied with its current performance. 
The top part of figure 1 displays the left-right ideology score of parties on the $x$-axis and a summary score ranging from opposition (3) to 21 (support) on the y-axis; the bottom part of figure 1 displays the way that parties evaluate the performance of the "EU Democracy." We included both the 2008 and 2013 scores in order to convey their position as well as any changes that may have taken place within individual parties. We note, first, that in 2008 there is only one party that is clearly EU-skepticalDie Linke party. It has traditionally viewed the market structures of the EU's integrated market with some suspicion. Although the left generally has become a bit more supportive over time of the EU as the supra-national institutions increasingly adopt a regulatory framework for the integrated economy, Die Linke at the extreme ideological left end of the party system is clearly seen as EU-critical in 2013 (along with the Pirate party). Moreover, it hardly changed its position since the onset of the economic crisis (and our surveys) in 2008. Thus, the left-polar end of the German party system supplied EU-critical voters with an established and distinct choice since at least 2008. In contrast, since we did not include the Alliance for Germany in our expert survey, there is no party in figure 1 that can be seen to articulate the critical EU orientations of conservative voters. This clearly illustrates why the AfD nearly succeeded in entering the Bundestag in the 2013 election on the basis of EU-critical stances (Schmitt-Beck this volume): it covers the "blind spot" of EU-skeptical representation. ${ }^{21}$

Figure 1 about here

Among mainstream parties, we see that the SPD was pro-EU principles in 2008 and by and large adopts the same position in 2013. This is consistent with the "reputational" perspective arguing that the SPD cannot move towards a more EU-skeptical position on the left without raising the salience of the issue and thereby increasing the relevance of Die Linke which has positioned itself as the owner of EUskepticism among Germany's left. We see a bit more movement among the Union, though this amounts to muting its previously strong support for the EU rather than expressing opposition to integration. To illustrate, the CDU decreased its support from an unequivocal support score of 18.2 (where 21 expresses 
maximum support) in 2008 to a 16.6 in 2013 . Thus, despite the changes, the 2013 score still falls squarely into the support category (see also below). Similarly, the CSU-which elevated the outspoken EU-critic Peter Gauweiler to a prominent position in recent years, is seen by experts as moving from moderate support to a more ambiguous position (mean=15.8 in 2008 and mean=13.5 in 2013). Despite these dynamics, we again note that these scores still mean that the CDU and to a lesser extent the CSU support Europe's integration. To illustrate, British Conservatives who are clearly among the most vocal EU skeptic party in the conservative, mainstream party camp, adopt a distinctly EU-skeptical position (mean=8.4 and mean=8.5 in 2008 and 2013, respectively).

We see virtually identical patterns for expert perceptions of how parties evaluate the performance of the EU. Most parties have become more negative about the performance of the EU between 2008 and 2013. However, we observe one noticeable outlier. The Greens have become significantly more supportive of EU principles reflecting their vocal support for the idea of a more integrated Europe in principle in order to sustain the EU. At the same time, however, the Greens have become significantly more negative about the performance of the EU, presumably because they are highly critical of the way the EU has structured financial rescue packages. Thus, the Greens remain a steadfast bearer of Europe's integration as an idea-but clearly lament its current performance and, indirectly, that of the German government's during the crisis.

All told, Germany's party system reflects two familiar camps even five years into the crisis. Mainstream parties in the ideological center support integration, and are fairly positive about the EU'S performance - the latter, possibly because certainly governing parties evaluate themselves. And we find the familiar opposition to the EU at the left and, now with the AfD, conservative polar end of Germany's party system.

\section{Party Stances in Comparison.}


To what extent are the positions of Germany's parties comparable to those in other countries? Was the response of German parties especially modest considering that economic fundamentals in Germany continued to look strong during our expert surveys (January 2013 through February 2014)? Given the relative economic tranquility in Germany in the year leading up to the election, we would like to know whether the fact that German parties were partly isolated from the economic shocks led to a uniquely positive or at least stable outlook on the EU. This is important not only to assess the political implications of the Germany-based patterns but also their theoretical relevance. For example, parties in Germany may not have changed their integration stances by much because there was no perceived economic and fiscal urgency to do so. Consequently, we would not want to conclude that the historically grown pro-EU reputation of German mainstream parties supports the reputational perspective when in fact the response among German parties is uniquely stable compared to other European parties, especially those in the same programmatic camp. If most other mainstream parties in Western Europe changed more substantially, then we would conclude that the German case provides only a restricted base to generalize from, though it is still relevant politically. For these reasons, we wish to examine the position of parties' integration stances in Western Europe, paying particular attention to where Germany's stances fall within this broader universe.

Figure 2 presents the scores for all 139 parties we have information for in Western Europe. The figures' layout is identical to that in figure 1 and conveys a simple but powerful conclusion: the major and minor parties fall squarely into the middle of their respective party camp. The Greens and the SPD at the center-left fall squarely into the pro-EU camp, continuing to advocate a "social vision" of Europe. ${ }^{22}$ Similarly, the support of the CDU and FDP is comparable to that of other center-right parties, though we note again that the CSU is moving towards a somewhat unusually strongly voiced EUskepticism amidst this camp, likely reflecting its unique position as a regional, Bavarian party. In turn, Die Linke and the Pirate party cover the left EU-skeptical spectrum in Germany. Their opposition is 
comparable to that of other left EU-skeptical parties, such as the Dutch and French Socialists. Finally, the placement of a range of EU-skeptical parties at the right spectrum outside of Germany shows that the AfD (not included in our surveys) appeals to the kind of voter that, for example, the Dutch PVV or the British UKIP attract.

Figure 2 about here

In addition to the absolute position of parties, we would also like to examine the degree to which changes in the German party system are comparable to those of other countries. To begin to describe the comparative dynamics, we first created two change scores of parties' EU position-one for each dependent variable, EU principles and the EU's performance. We subtracted the 2013 score from the 2008 scores. A positive score means that parties have increased their support for EU principles and the EU's democracy by 2013; a negative score means that parties have become more EU-skeptical over time. Figure 3 displays the scatterplot with the labels of German parties to convey the amount of change relative to other European parties $(\mathrm{N}=90)$. The $\mathrm{y}$-axis displays the change scores; the $\mathrm{x}$-axis shows parties' left-right placement scores. Given that this comparison requires that parties were politically relevant as defined earlier, this analysis does not include new anti-EU skeptic parties that evolved since our first survey (e.g., the Italian M5S).

Figure 3 indicates, first, that most parties are located within one plus/-minus unit change of the 0 line which denotes identical positions in 2008 and 2013. This suggests that most parties did not change their position by much over time. However, to say that change is completely absent would be inaccurate. For example, the most dramatic turn against the EU between 2008 and 2013 is found in Hungary where FIDESZ under Victor Orban's stewardship has become very EU-skeptical (a five point drop in support for EU principles). In Western Europe, the most negative turn is found in Denmark where the conservative Liberal Alliance (NA) moved nearly 4 points towards EU-skepticism by 2013 (mean= -3.8) followed by the Duch PVV (mean =-3.6). Visually, being located in the lower right quadrant, 
we see that the CDU and CSU are also among the parties that turned noticeably away by about 2 points from its previously strong support when compared to the West European universe. The comparatively significant change in the Union is particularly noticeable when we focus on governing parties only (figure 4) where we observe the strongest turn against Europe within the West among incumbents. However, these developments should not lead us to overlook that both parties still fall into the "support" territory (as figures 1 and 2 indicate).

Figures 3 and 4 about here

All told, the change among German parties is comparatively non-trivial and suggests that the electoral campaign of the AfD has left its imprint on the position of these parties. But we also note that the governing CDU/CSU continues to support EU principles, though clearly in more muted form. In contrast, the SPD is nearly exactly at the same location where it was positioned in 2008 which is quite astounding given that it had one of the worst election results in the 2009 federal election. ${ }^{23}$

In a final step, we systematically examine the degree to which the German parties are different from their programmatic families in 2008 and 2013. We do so in order to triangulate the question whether Germany's mainstream parties are unique in their sustained support for the EU when compared to parties from the same ideological families elsewhere in Western Europe. To this end, we conducted several multiple regression analyses predicting party stances on EU principles and their evaluations of the EU democracy. We estimate the models using 2008-2013 data for parties that were included at both surveys. We include four independent variables: a party family dummy variable which captures whether a party is a socialist, green, social democrat, liberal, or Christian Democrats. These represent the party families represented in the German party system in our expert survey. Then, we added the year a survey was conducted (2008 is coded " 0 " and 2013 coded as " 1 "). Third, we included a dummy variable indicating whether parties are from Germany ("1") or from another West European country (" 0 "). Finally, we include a triple interaction effect between these three variables. The goal is to 
assess whether the position of (to name one example) the CDU/CSU in 2008 is different from Christian Democrats elsewhere in 2008; and then to see whether this difference has changed by 2013.

While the models are easily estimated in the pooled data ( $N=180 ; 90$ for each year), the interpretations of a triple interaction effect is quite difficult without further information. We therefore computed the predicted values for each party family within Germany (by year) and for other West European countries (table 3). Take for example, the predicted values of the CDU/CSU. The model predicts a value of 17.3 for 2008 and a decline by 2013 to 15.1 . While we observed a change in figures 2 and 3, we now also see that the Union stays more positive than other Christian Democrats in Western Europe $(2008$ score=13.7; 2013 score=13.1). Within the Christian Democratic party family, therefore, the analyses suggest that the Union remains quite supportive of integration compared to its ideological cousins even though it also reduced its enthusiasm for EU principles by more than most Christian Democratic parties. In short, it has become more muted in its support but maintains its support at levels that a bit more positive than that of other members of this party family. This shows that an analysis of change alone can be quite misleading if one were led to infer from it that the CDU/CSU has become uniquely skeptical about integration.

The SPD, in contrast, stays nearly exactly where it was in 2008 (16.7 versus 16.2 on EU principles); a pattern we also find for party stances on the EU's democracy. This pattern closely matches that of other Social Democrats in Europe which barely changed during the five year crisis. A similar conclusion emerges about the FDP which remains positive and also duplicates the Europe-wide pattern. The one exception we noted earlier-and see confirmed here-concerns the German Greens: they are considerably more positive about EU principles than other green parties in Europe and, moreover, they have become quite skeptical about the EU's performance, again in contrast to green parties elsewhere, though we do note that the Greens were unusually positive in 2008. Overall, the Green's position on the 
EU's performance now closely fits with the rest of Green European parties, though they do stay considerably more positive about EU principles than other Green parties in Western Europe.

Table 3 about here

\section{Conclusion}

To recap, we observe that EU stances produce a curvilinear pattern when viewed on the basis of a left-right perspective, just as elsewhere in Western Europe. The SPD is rather positive about the EU, and remains so during the crisis; the Union also remains quite positive, albeit at a more muted level. In contrast, Die Linke party is fairly negative, presumably because it rejects the pro-market framework of the EU and, moreover, the austerity-based rescue packages for ailing economies. Moreover, while the AfD is not included in our expert survey, our study still suggests that it presumably entered the electoral market precisely where mainstream parties left an opening at the conservative polar end where market preferences coincide with nationalism and EU-skepticism (Schmitt-Beck this volume).

Theoretically, our paper shows that it is very difficult for mainstream parties to move towards a more skeptical position. It thus supports the reputational argument more so than the spatial perspective, at least as far as mainstream parties are concerned. For extreme parties, on the other hand, the combination of an anti-EU stance, along with a growing EU skepticism, seems to be a winning formula, certainly for the AfD and Die Linke party. So, when viewed from the mainstream perspective, the reputational mechanism appears to conflict with the spatial mechanisms; but when viewed from the perspective of extreme parties, the two mechanisms reinforce each other.

Finally, we would like to raise one issue that is potentially lurking behind our findings: why did the CDU/CSU begin to respond to the EU-skeptic threat of the AfD, whereas the SPD does not appear to respond at all to the EU-skeptic threat from Die Linke? We may see here the differential threat potential each party faces as a result of the novelty of a challenger. Die Linke is firmly established in the German 
party system, and thus has had time to develop a loyal voter clientele, as well as to develop its reputation and competence as a critic of the integrated market. This makes it difficult for the SPD to position itself as the "original" EU-skeptic at the left end of Germany's party system. In contrast, the AfD is new and thus lacks these support pillars so that it made sense for the CDU/CSU to stem the potential defection of its own voters to the AfD on the basis of its EU-skepticism. Thus, the CDU/CSU may be better positioned to absorb EU-skeptic voters than the SPD-though whether or not this is a viable strategy for the Union, only time will tell. 


\section{The expert survey}

\section{Appendix}

We conducted a Europe-wide expert survey in 2007-2008. The CEE survey covers 94 parties in 13 Central-East European countries (all then-EU nations, plus Moldova, Russia, and the Ukraine); the WE survey covers 104 parties in all EU countries minus Luxembourg. ${ }^{1}$ We conducted a second expert survey throughout 2013, covering many of the same parties in CEE and WE but also a number of newly founded parties. We asked experts, who were identified on the basis of their publication record on a given party system, to complete a detailed questionnaire. For each country, we strove to obtain 10 expert responses which we achieved in many instances (table A1). We use here mostly the results from the expert survey in Germany ( $N=10$ in 2008; $N=9$ in 2013). See appendix table $A 1$ for details on parties included in the West European surveys and response rates for all countries.

\section{Indicators}

Political Divisions:

Question wording is presented in the main text. Respondents were shown the following card and indicated whether a cleavage is the $1^{\text {st }}, 2^{\text {nd }}, 3^{\text {rd }}$, or $4^{\text {th }}$ most important cleavage. If an expert did not select a cleavage, it was coded as " 5 ".

A. Economy: redistributional issues (for example, tax levels, welfare state spending)

B. Economy: State-run versus market economy

C. Democracy: strengthening democratic institutions

D. Ethnic rights (for example, minorities)

E. Nationalism and Internationalism (for example, views about the EU)

F. Religiosity (role of church)

G. Social Rights

$\mathrm{H}$. Views of the Communist past and its legacies (issue $\mathrm{J}$ in 2013; was re-coded to $\mathrm{H}$ for consistencies' sake)

I. Regional Divisions

J. Urban-rural divisions

\section{Party's left-right ideology:}

"In [country], parties may be located to the left or the right of the political spectrum. In general terms, please locate each party on the ideological spectrum in [country], with 1 standing for left wing, and 7 standing for right wing."

\section{West Integration:}

Presented in text.

\section{Political integration:}

Presented in text.

\section{Market Integration:}

Presented in text.

EU Democracy performance:

Presented in text. 
${ }^{1}$ Downs, A. (1957). An Economic Theory of Democracy. New York, Harper\&Row; Westholm, A. (1997). "Distance versus Direction: The Illusory Defeat of the Proximithy Theory of Electoral Choice." American Political Science Review 91: 865-883.

${ }^{2}$ Hooghe, L. and G. Marks (2008). "A Postfunctionlist Theory of European Integration: From Permissive Consensus to Constraining Dissensus." British Journal of Political Science 39: 1-23; Lindberg, L. N. and S. A. Scheingold, Eds. (1970). Regional Integration: Theory and Research Cambridge, Cambridge University Press.

${ }^{3}$ Paterson, W. E. (2010). "Does Germany Still Have a European Vocation?" German Politics 19(1): 41-52.

${ }^{4}$ For a detailed discussion of the expert surveys conducted in 27 European countries, see Robert Rohrschneider and Stephen Whitefield. 2012. The Strain of Representation. Oxford: Oxford University Press.

${ }^{5}$ Maier, M., et al. (2012). "The impact of identity and economic cues on citizens' EU support: An experimental study on the effects of party communication in the run-up to the 2009 European Parliament elections." European Union Politics 13(4): 580-603; Marsh, M. (2005). European Parliament Elections and losses by governing parties. European Elections and Domestic Politics. W. Van der Brug and C. v. d. Eijk. Notre Dame, University of Notre Dame: 51-72.

${ }^{6}$ See, for example, https://en.wikipedia.org/wiki/European Stability Mechanism (Accessed 06-302015) which shows that Germany committed over 190 billion Euros to the European Stability Mechanism. As a reference point, this is over half of its 2015 annual budget.

${ }^{7}$ Roth, F., et al. (2013). Crisis and Trust in National and European Union Institutions--Panel Evidence for the EU, 1999-2012. RSCAS Working Papers. Florence, European University Institute. 2013/31.

${ }^{8}$ Bechtel, M. M., et al. (2014). "Preferences for International Redistribution: The Divide over the Eurozone Bailouts." American Journal of Political Science 58(4): 835-856.

${ }^{9}$ Wimmel, A. and E. E. Edwards (2011). "The Return of 'Social Europe': Ideas and Positions of German Parties towards the Future of European Integration." German Politics 20(2): 293-314.

${ }^{10}$ Pappi, F. U. and P. W. Thurner (2000). "Die deutschen Waehler und der Euro: Auswirkungen auf die Bundestagswahl 1998." Politische Vierteljahresschrift 41(3): 435-465; Paterson, W. E. (2010). "Does Germany Still Have a European Vocation?" German Politics 19(1): 41-52.

${ }^{11}$ Budge, I. (1994). "A New Spatial Theory of Party Competition: Uncertainty, Ideology and Policy Equilibria Viewed Comparatively and Temporally." British Journal of Political Science 24(4): 443-467.

${ }^{12}$ Doerschler, P. and L. A. Banaszak (2007). "Voter support for the German PDS over time: Dissatisfaction, ideology, losers, and east identity." Electoral Studies 87(2): 359-370; Vail, M. I. and B. Bowyer (2012). "Poverty and parisanship: Social and economic sources of support for the far Left in contemporary Germany." Comparative European politics 10(4): 505-524. 
${ }^{13}$ Wagner, M. (2012). "Defining and measuring niche parties." Party Politics 18(6): 845-864; Rovny, J. (2012). "Who emphasizes and who blurs? Party strategies in multidimensional competition." European Union Politics 13(2): 269-292.

${ }^{14}$ Berbuir, N., et al. (2015). "The AfD and its Sympathisers: Finally a Right-Wing Populist Movement in Germany?" German Politics.

${ }^{15}$ Pappi, F. U. (1977). "Sozialstruktur, gesellschaftliche Wertorientierungen und Wahlabsicht. Ergebnisse eines Zeitvergleichs des deutschen Elektorats 1953 und 1976." Politische Vierteljahresschrift 18: 195229; Debus, M. and J. Müller (2013). "The Programmatic Development of CDU and CSU since Reunification: Incentives and Constraints for Changing Policy Positions in the German Multi-Level System." German Politics 22(1-2): 151-171.

${ }^{16}$ Roßteutscher, S. (2012). Die konfessionell-religiőse Konfliktlinie zwischen Säkularisierung und Mobilisierung. Wählen in Deutschland. R. Schmitt-Beck. Baden-Baden, Nomos: 111-133;

${ }^{17}$ Müller , W. and M. Klein (2012). Die Klassenbasis in der Parteipräferenz des deutschen Wählers. Erosion oder Wandel? Wählen in Deutschland R. Schmitt-Beck. Baden-Baden, Nomos: 85-110; Pappi, F. U. and J. Brandenburg (2012). Die Politikvorschlaege der Bundestagsparteien aus Wa"hlersicht: Zur Konstruierbarkeit von Politikra"umen fu" $r$ das deutsche Parteiensystem. Waehlen in Deutschland. R. Schmitt-Beck. Baden-Baden, Nomos: 276-301.

${ }^{18}$ Brug, W. v. d. and J. v. Spanje (2009). "Immigration, Europe, and the Cultural Dimension." European Journal of Political Research 48: 309-334; Kriesi, H. (2007). "The Role of European Integration in National Election Campaigns." European Union Politics 8(1): 83-108.

${ }^{19}$ The expert survey was conducted by the authors in 2007/2008 and repeated in 2013 with an identical questionnaire in 24 European democracies for about 200 parties. Experts were chosen on the basis of their prior publication record which stipulated that they had to have published a book or article on her party system in the past 10 years. We aimed to have 10 completed questionnaires per country; a goal we met for Germany at both time points. See Rohrschneider and Whitefield (2012) and the appendix for a description of the study.

${ }^{20}$ For West European parties in our data $(\mathrm{N}=108)$, alpha $=.90$.

${ }^{21}$ Thomassen, J. (2012). "The Blind Corner of Political Representation." Representation 41(1): 13-27.

${ }^{22}$ Wimmel, A. and E. E. Edwards (2011). "The Return of 'Social Europe': Ideas and Positions of German Parties towards the Future of European Integration." German Politics 20(2): 293-314.

${ }^{23}$ Of course, it may be that it has moved more on domestic divisions given that Europe's integration does not constitute the most important cleavage. Additional analyses, however, indicate that the SPD has not changed its domestic issue stances by much either. 
Table 1 Public Support for European Integration in Germany, 2009-2014

Germany's Membership in the EU is:

Integration has gone:

\begin{tabular}{|l|l|l|l|l|l|l|}
\hline & 2009 & 2014 & & & 2009 & 2014 \\
\hline Good & 77.7 & 68.5 & & Too far & 34.2 & 42.5 \\
\hline Neither & 15.8 & 23.8 & & Neutral & 22 & 21.3 \\
\hline Bad & 6.5 & 7.8 & & Push further & 43.8 & 35.2 \\
\hline N & 999 & 1624 & & & 999 & 1559 \\
\hline & & & & & & \\
\hline & & & & & \\
\hline
\end{tabular}

Sources: European Election Studies 2009, 2014.

Membership: "Generally speaking, do you think that (OUR COUNTRY)'s membership of the EU is...? Integration pace: "Some say European unification should be pushed further. Others say it already has gone too far. What is your opinion? Please indicate your views using a scale from 0 to 10 , where ' 0 ' means unification "has already gone too far" and '10' means it "should be pushed further". What number on this scale best describes your position?" Too far (0-4); neutral (5), push further (6-10). 
Table 2: The most Important Divisions in Germany's Party System, 2008-2013

\begin{tabular}{|l|c|c|c|}
\hline & Spring 2008 & Spring 2013 & \\
\hline $\begin{array}{l}\text { Redistribution } \\
\text { (welfare state) }\end{array}$ & 1 & 1 & \\
\hline $\begin{array}{l}\text { Cultural issues (gay } \\
\text { rights; } \\
\text { environmentalism) }\end{array}$ & 2 & 2 & \\
\hline $\begin{array}{l}\text { Markets vs state } \\
\text { control of economy }\end{array}$ & 3 & 3 & \\
\hline $\begin{array}{l}\text { Nationalism vs. } \\
\text { internationalism } \\
\text { (European } \\
\text { integration) }\end{array}$ & 4 & 3 & \\
\hline
\end{tabular}

Entries indicate the importance of political divisions in Germany's party system.

Source: All party level data in this table and figures 2-6 are taken from two expert surveys conducted in Germany in 2008 and 2013 (see the appendix for a description). A "1" indicates that a division is the most important; "2" second most important, etc. 
Table 3: Predicted EU principles and EU Democracy Evaluations for major parties in Germany and corresponding party families elsewhere in Western Europe 2008-2013

\begin{tabular}{|l|l|c|c|c|c|c|}
\hline & & 2008 & 2013 & & 2008 & 2013 \\
\hline & & \multicolumn{2}{|c|}{ EU Principles } & \multicolumn{2}{|c|}{ EU Democracy } \\
\hline Germany & CDU/CSU & 17.3 & 15.1 & 4.6 & 3.9 \\
\hline & Liberals & 18.1 & 17.1 & 4.5 & 4.4 \\
\hline & SPD & 16.7 & 16.2 & & 4.3 & 3.9 \\
\hline & Greens & 15.3 & 17.1 & & 4.1 & 3.1 \\
\hline & Die Linke & 9.2 & 9.3 & & 2.3 & 1.9 \\
\hline & & & & & & \\
\hline $\begin{array}{l}\text { Western } \\
\text { Europe }\end{array}$ & $\begin{array}{l}\text { Christian } \\
\text { Democrats }\end{array}$ & 13.7 & 13.1 & & 3.9 & 4.2 \\
\hline & Liberals & 16.4 & 16.1 & & 4.4 & 3.9 \\
\hline & $\begin{array}{l}\text { Social } \\
\text { Democrats }\end{array}$ & 15.6 & 15.5 & 4.4 & 4.6 \\
\hline & Greens & 12.2 & 13.9 & & 2.8 & 3.2 \\
\hline & Socialists & 7.7 & 8.2 & & 2.4 & 2.1 \\
\hline
\end{tabular}

Note: Cell entries are predicted values from several multi-level analysis with EU principles and performance as the dependent variables. Independent variables are: three dummy variables: year of survey (2013 vs. 2008), Germany (1 yes 0 other); party family (dummy for each family analyzed in separate models); and a triple interaction effect between them. We estimated two models for each party family. For example, for Christian Democrats (CD), we estimated one model with EU principles and one with EU performance as the dependent variable. Independent variables for CDs are: year, country, a dummy for CDs; and an interaction effect of year*country*CD. On the basis of the coefficients, we then calculated the predicted values of EU principles for the CDU/CSU in 2008 (17.3) and 2013 (15.1). The same model estimates were also used to calculate the predicted values for Christian Democrats in Western Europe (13.7 in 2008 and 13.1 in 2013). We then estimated models for other party families analogously (e.g., for the SPD, we replace the CD dummy with a Social Democrat dummy, and calculated predicted values for the SPD and Social Democrats). We repeated this for every party family shows in table 2. 
Table A1: Parties included in 2008 and 2013 surveys (2008 and 2013 entries list the number of experts who completed a survey for a party system in a given year.)

\begin{tabular}{|c|c|c|c|c|c|}
\hline Country: West & Party Name in RW survey & Acronym & 2008 & 2013 & Party family \\
\hline Austria & Social Democratic Party of Austria & SPO & Yes & Yes & Social-democrat \\
\hline 2008: 10 & Austrian People's Party & OVP & Yes & Yes & Christian-democrat \\
\hline \multirow[t]{4}{*}{ 2013: 9} & The Greens & GRUNE & Yes & Yes & Green \\
\hline & Freedom Party of Austria & FPO & Yes & Yes & Nationalist \\
\hline & Alliance for the Future of Austria & $\mathrm{BZO}$ & Yes & Yes & Nationalist \\
\hline & Team Stronach & TS & No & Yes & Nationalist \\
\hline Belgium & Christian-Democratic \& Flemish & CDV & Yes & Yes & Christian-democrat \\
\hline 2008: 10 & New Flemish Alliance & $\mathrm{N}-\mathrm{VA}$ & Yes & Yes & Conservative/Separatist \\
\hline \multirow[t]{10}{*}{ 2013: 8} & Reform Movement & $\mathrm{MR}$ & Yes & Yes & Centrist \\
\hline & Flemish Interest & VB & Yes & Yes & Nationalist \\
\hline & Flemish Liberals and Democrats & VLD & Yes & Yes & Centrist \\
\hline & Socialist Party & PS & Yes & Yes & Social-democrat \\
\hline & Socialist Party. Different & SPA & Yes & Yes & Social-democrat \\
\hline & Humanist Democratic Centre & $\mathrm{CDH}$ & Yes & Yes & Christian-democrat \\
\hline & Ecologists & ECOLO & Yes & Yes & Green \\
\hline & List Dedecker & LDD & Yes & Yes & Nationalist \\
\hline & The Flemish Greens & GROEN & Yes & Yes & Green \\
\hline & National Front & $\mathrm{FN}$ & Yes & No & Nationalist \\
\hline Denmark & Denmark's Liberal Party & $\mathrm{V}$ & Yes & Yes & Conservative \\
\hline 2008: 9 & Social Democracy & $\mathrm{S}$ & Yes & Yes & Social-democrat \\
\hline \multirow[t]{6}{*}{ 2013: 9} & Danish People's Party & DF & Yes & Yes & Nationalist \\
\hline & Socialist People's Party & SF & Yes & Yes & Socialist \\
\hline & Conservative People's Party & $\mathrm{KF}$ & Yes & Yes & Conservative \\
\hline & Radical Liberals & $\mathrm{RV}$ & Yes & Yes & Centrist \\
\hline & Unity List - The Red-Greens & $\mathrm{EL}$ & Yes & Yes & Socialist \\
\hline & Liberal Alliance (2008: New Alliance) & NA & Yes & Yes & Conservative \\
\hline Finland & Finnish Centre & KESK & Yes & Yes & Centrist \\
\hline 2008: 9 & National Coalition Party & KOK & Yes & Yes & Conservative \\
\hline \multirow[t]{6}{*}{ 2013: 8} & Finnish Social Democratic Party & SDP & Yes & Yes & Social-democrat \\
\hline & Left Alliance & VAS & Yes & Yes & Socialist \\
\hline & Green Alliance & VIHR & Yes & Yes & Green \\
\hline & Finnish Christian Democrats & $\mathrm{KD}$ & Yes & Yes & Christian-democrat \\
\hline & Swedish People's Party in Finland & SFP & Yes & Yes & Centrist \\
\hline & True Finns & PS & Yes & Yes & Nationalist \\
\hline France & Union for a Popular Movement & UMP & Yes & Yes & Conservative \\
\hline 2008: 10 & Socialist Party & PS & Yes & Yes & Social-democrat \\
\hline \multirow[t]{7}{*}{ 2013: 6} & Democratic Movement & MoDem & Yes & Yes & Centrist \\
\hline & French Communist Party & PCF & Yes & No & Communist \\
\hline & National Front & $\mathrm{FN}$ & Yes & Yes & Nationalist \\
\hline & The Greens & VERTS & Yes & Yes & Green \\
\hline & New Centre & NC & Yes & Yes & Conservative \\
\hline & Radical Party of the Left & PRG & Yes & Yes & Social-democrat \\
\hline & Movement for France & MPF & Yes & No & Nationalist \\
\hline $\begin{array}{l}\text { Merges with } \\
\text { FDG }\end{array}$ & Communist Revolutionary League & LCR & Yes & No & Communist \\
\hline
\end{tabular}




\begin{tabular}{|c|c|c|c|c|c|}
\hline & Radical Party & PR & No & Yes & Centrist \\
\hline & Left Front & FDG & No & Yes & Communist \\
\hline & Centrist Alliance & $A C$ & No & Yes & Centrist \\
\hline Germany & Christian Democracy Union & CDU & Yes & Yes & Christian-democrat \\
\hline 2008: 10 & Christian Social Union & CSU & Yes & Yes & Christian-democrat \\
\hline \multirow[t]{5}{*}{ 2013: 9} & Social Democratic Party of Germany & SPD & Yes & Yes & Social-democrat \\
\hline & Free Democratic Party & FDP & Yes & Yes & Centrist \\
\hline & $\begin{array}{l}\text { The Left (Party of Democratic } \\
\text { Socialism, PDS) }\end{array}$ & DIE LINKE & Yes & Yes & Socialist \\
\hline & Alliance 90/The Greens & GRUNE & Yes & Yes & Green \\
\hline & Piratenpartei & Piraten & No & Yes & Centrist \\
\hline Greece & New Democracy & ND & Yes & Yes & Centrist \\
\hline 2008: 10 & Panhellenic Socialist Movement & PASOK & Yes & Yes & Social-democrat \\
\hline \multirow[t]{7}{*}{ 2013: 9} & Communist Party of Greece & KKE & Yes & Yes & Communist \\
\hline & $\begin{array}{l}\text { Coalition of the Left, the Movements } \\
\text { and the Ecology }\end{array}$ & SYN & Yes & No & Socialist \\
\hline & Popular Orthodox Rally & LAOS & Yes & No & Nationalist \\
\hline & Coalition of the Radical Left & SYRIZA & No & Yes & Socialist \\
\hline & Independent Greeks & ANEL & No & Yes & Nationalist \\
\hline & Golden Dawn & $X A$ & No & Yes & Nationalist \\
\hline & Democratic Left & DIMAR & No & Yes & Socialist \\
\hline Ireland & & $\mathrm{FF}$ & Yes & Yes & Social-democrat \\
\hline 2008: 10 & Fine Gael & FG & Yes & Yes & Conservative \\
\hline \multirow[t]{6}{*}{ 2013: 7} & Labour Party & LAB & Yes & Yes & Social-democrat \\
\hline & Sinn Fein & SF & Yes & Yes & Centrist \\
\hline & Green Party & GP & Yes & Yes & Green/Socialist \\
\hline & Progressive Democrats & PD & Yes & No & Centrist \\
\hline & Socialist & SP & Yes & Yes & Socialist \\
\hline & People Before Profit Alliance & PBP & No & Yes & Communist \\
\hline Italy & Left Democrats & Left_Dem & Yes & Yes & Social-democrat \\
\hline 2008: 10 & Communist Refoundation Party & PRC & Yes & No & Communist \\
\hline \multirow[t]{13}{*}{ 2013: 8} & Italian Democratic Socialists & SDI & Yes & No & Social-democrat \\
\hline & Italian Radicals & RI & Yes & No & Centrist \\
\hline & Party of Italian Communists & $\mathrm{PdCl}$ & Yes & No & Communist \\
\hline & Italy of Values & $\mathrm{IdV}$ & Yes & No & Centrist \\
\hline & Green Federation & VERDI & Yes & No & Green \\
\hline & Forward Italy & $\mathrm{FI}$ & Yes & No & Conservative \\
\hline & National Alliance & AN & Yes & No & Nationalist \\
\hline & $\begin{array}{l}\text { Union of Christian and Centre } \\
\text { Democrats }\end{array}$ & UDC & Yes & No & Christian-democrat \\
\hline & League North & $\mathrm{LN}$ & Yes & Yes & Nationalist/Separatist \\
\hline & The People of Freedom & PDL & No & Yes & Christian-democrat \\
\hline & Union of the Centre & UDC & No & Yes & Christian-democrat \\
\hline & Five Star Movement & M5S & No & Yes & Other \\
\hline & Civic Choice & SC & No & Yes & Centrist \\
\hline Netherlands & Christian Democratic Appeal & CDA & Yes & Yes & Christian-democrat \\
\hline 2008: 9 & Labour Party & PvdA & Yes & Yes & Social-democrat \\
\hline
\end{tabular}




\begin{tabular}{|c|c|c|c|c|c|}
\hline \multirow[t]{10}{*}{ 2013: 9} & Socialist Party & $\mathrm{SP}$ & Yes & Yes & Socialist \\
\hline & $\begin{array}{l}\text { People's Party for Freedom and } \\
\text { Democracy }\end{array}$ & VVD & Yes & Yes & Conservative \\
\hline & Freedom Party & PVV & Yes & Yes & Conservative \\
\hline & Green Left & $\mathrm{GL}$ & Yes & Yes & Green \\
\hline & Christian Union & $\mathrm{CU}$ & Yes & Yes & Christian-democrat \\
\hline & Democrats 66 & D66 & Yes & Yes & Centrist \\
\hline & Party for the Animals & PvdD & Yes & Yes & Green \\
\hline & List Rita Verdonk & VERDONK & Yes & No & Centrist \\
\hline & Reformed Political Party & SGP & Yes & Yes & Christian-democrat \\
\hline & 50 Plus & $50+$ & No & Yes & Centrist \\
\hline Portugal & Socialist Party & PS & Yes & Yes & Social-democrat \\
\hline 2008: 10 & Social Democratic Party & PSD & Yes & Yes & Conservative \\
\hline \multirow[t]{4}{*}{ 2013: 7} & Portuguese Communist Party & PCP & Yes & Yes & Communist \\
\hline & Ecological Party The Greens & PEV & Yes & No & Green \\
\hline & Democratic Social Centre & CDS-PP & Yes & Yes & Conservative \\
\hline & Left Bloc & $\mathrm{BE}$ & Yes & Yes & Socialist \\
\hline Spain & Spanish Socialist Workers' Party & PSOE & Yes & Yes & Social-democrat \\
\hline 2008: 10 & People's Party & PP & Yes & Yes & Conservative \\
\hline \multirow[t]{12}{*}{ 2013: 9} & United Left & IU & Yes & Yes & Socialist \\
\hline & Initiative for Catalonia Greens & ICV & Yes & Yes & Green \\
\hline & Convergence and Union of Catalonia & $\mathrm{CiU}$ & Yes & Yes & Centrist \\
\hline & Republican Left of Catalonia & ERC & Yes & No & Nationalist/Separatist \\
\hline & Basque National Party & EAJ-PNV & Yes & Yes & Nationalist/Separatist \\
\hline & Canarian Coalition & $\mathrm{CC}$ & Yes & No & Centrist/Separatist \\
\hline & Galician Nationalist Bloc & BNG & Yes & No & Socialist/Separatist \\
\hline & Basque Solidarity & EA & Yes & No & Nationalist/Separatist \\
\hline & Aragonese Council & $\mathrm{CHA}$ & Yes & No & Socialist/Separatist \\
\hline & Navarre Yes & Na-Bai & Yes & No & Nationalist/Separatist \\
\hline & Union, Progress, and Democracy & UPyD & No & Yes & Centrist \\
\hline & Amaiur & AMAIUR & No & Yes & Socialist \\
\hline Sweden & Social Democratic Workers' Party & SAP & Yes & Yes & Social-democrat \\
\hline 2008: 10 & Moderate Rally Party & M & Yes & Yes & Conservative \\
\hline \multirow[t]{6}{*}{ 2013: 7} & Centre Party & $\mathrm{C}$ & Yes & Yes & Conservative \\
\hline & Liberal People's Party & FP & Yes & Yes & Centrist \\
\hline & Christian Democrats & KD & Yes & Yes & Christian-democrat \\
\hline & Left Party & VP & Yes & Yes & Socialist \\
\hline & Environment Party The Greens & $\mathrm{MP}$ & Yes & Yes & Green \\
\hline & Sweden Democrats & SD & Yes & Yes & Nationalist \\
\hline UK & Labour Party & LAB & Yes & Yes & Social-democrat \\
\hline 2008: 10 & Conservative Party & CON & Yes & Yes & Conservative \\
\hline \multirow[t]{4}{*}{ 2013: 7} & Liberal Democrats & LD & Yes & Yes & Centrist \\
\hline & Scottish National Party & SNP & Yes & Yes & $\begin{array}{l}\text { Social- } \\
\text { democrat/Separatist }\end{array}$ \\
\hline & Plaid Cymru & PC & Yes & Yes & $\begin{array}{l}\text { Social- } \\
\text { democrat/Separatist }\end{array}$ \\
\hline & UK Independence Party & UKIP & No & Yes & Nationalist \\
\hline
\end{tabular}


Figure 1 Party Position on European Integration in 2008 and 2013

EU Principles:

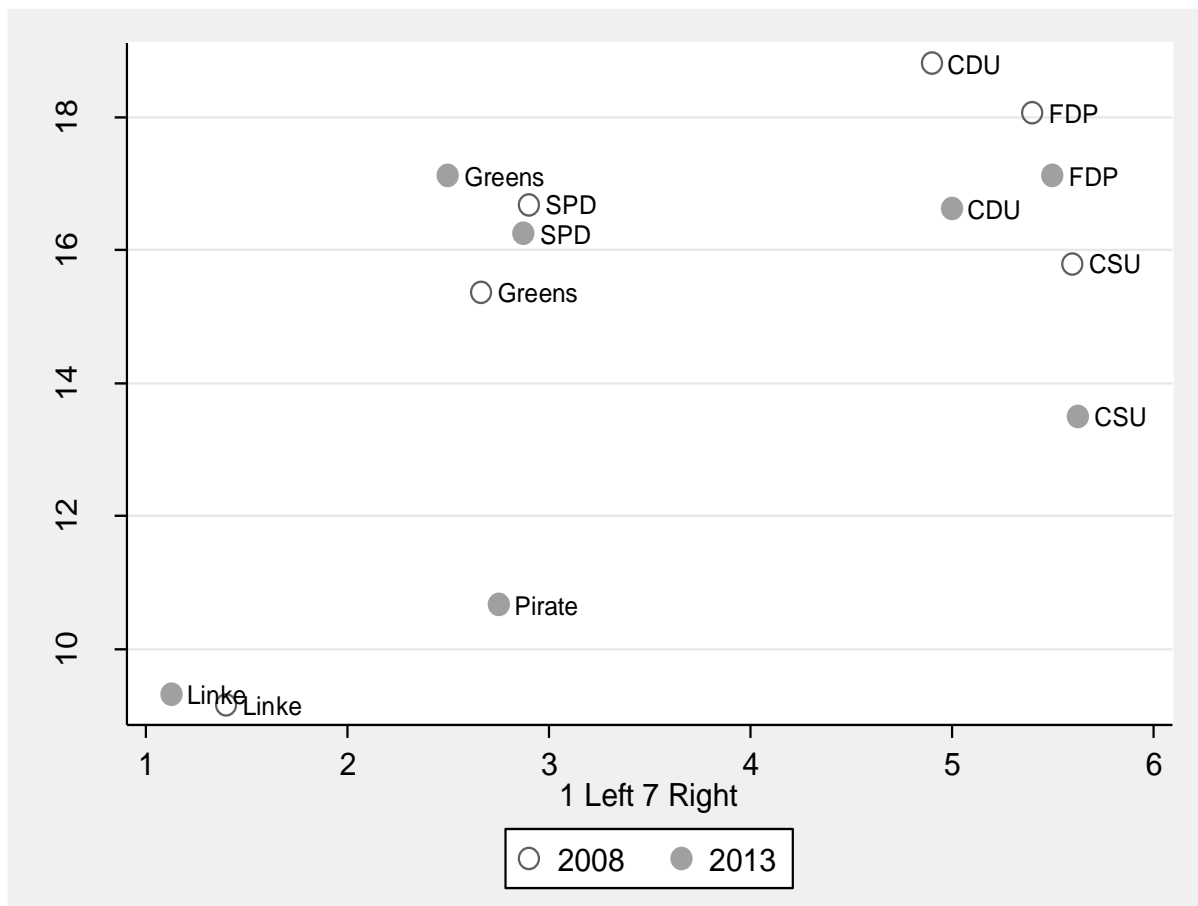

EU Democracy:

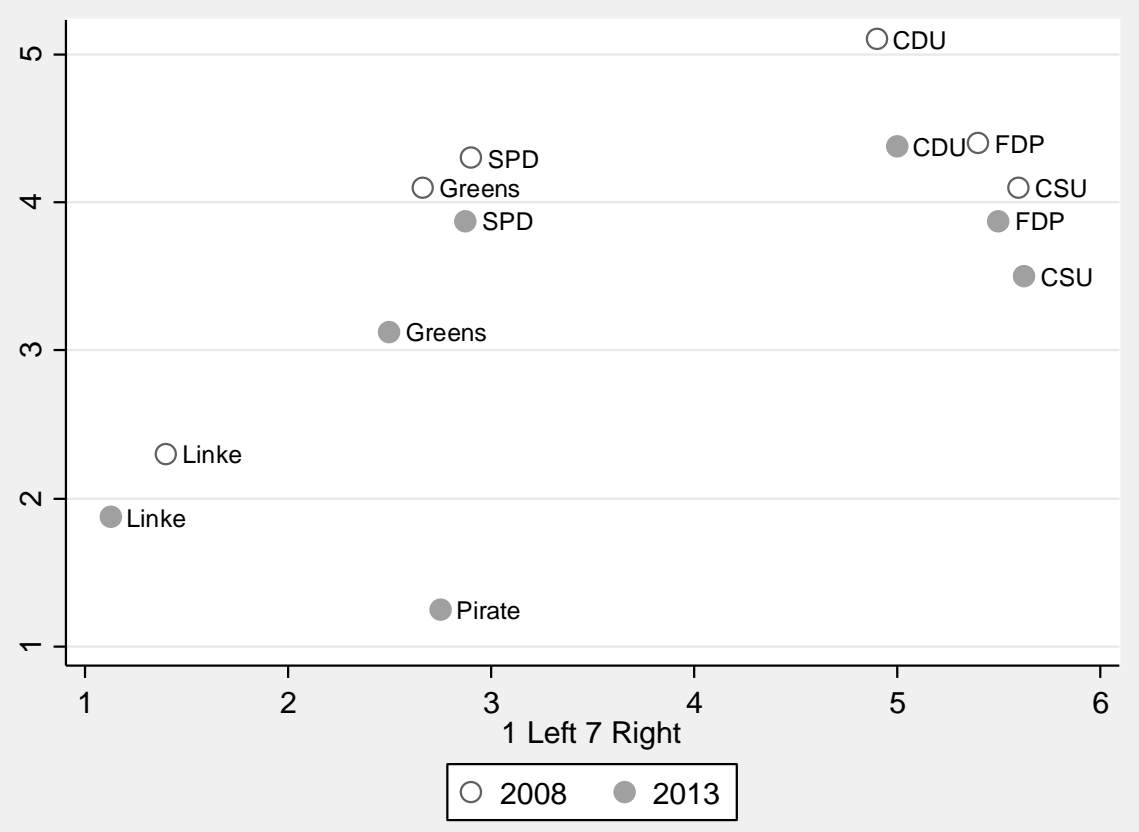


Note: Entries are mean ideology scores of parties on the x-axis (1-7); mean scores on the EU-principles indicator (3-21); and mean scores on the EU democracy indicator (1-7) in the bottom figure.

Figure 2: Integration Stances of German Parties in Comparison, 2013:

EU Principles:

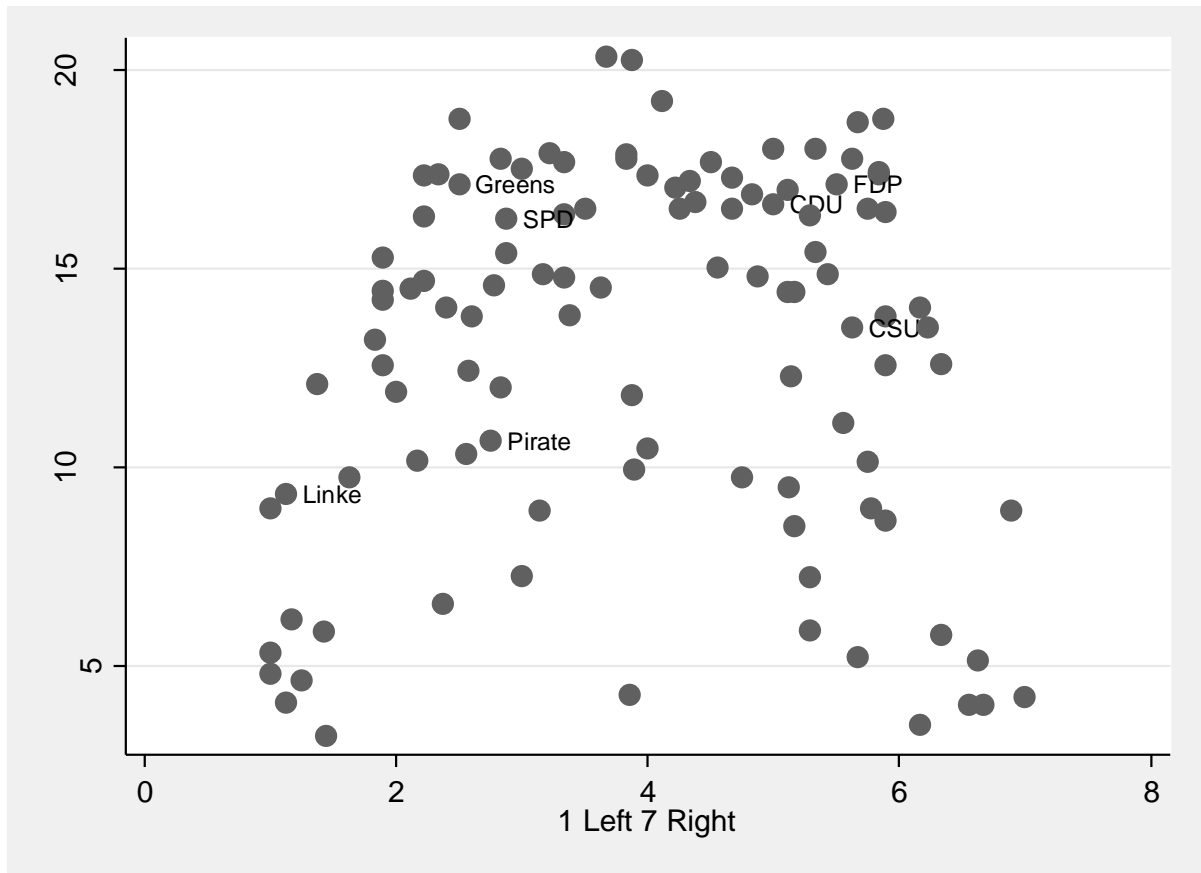

EU Democracy

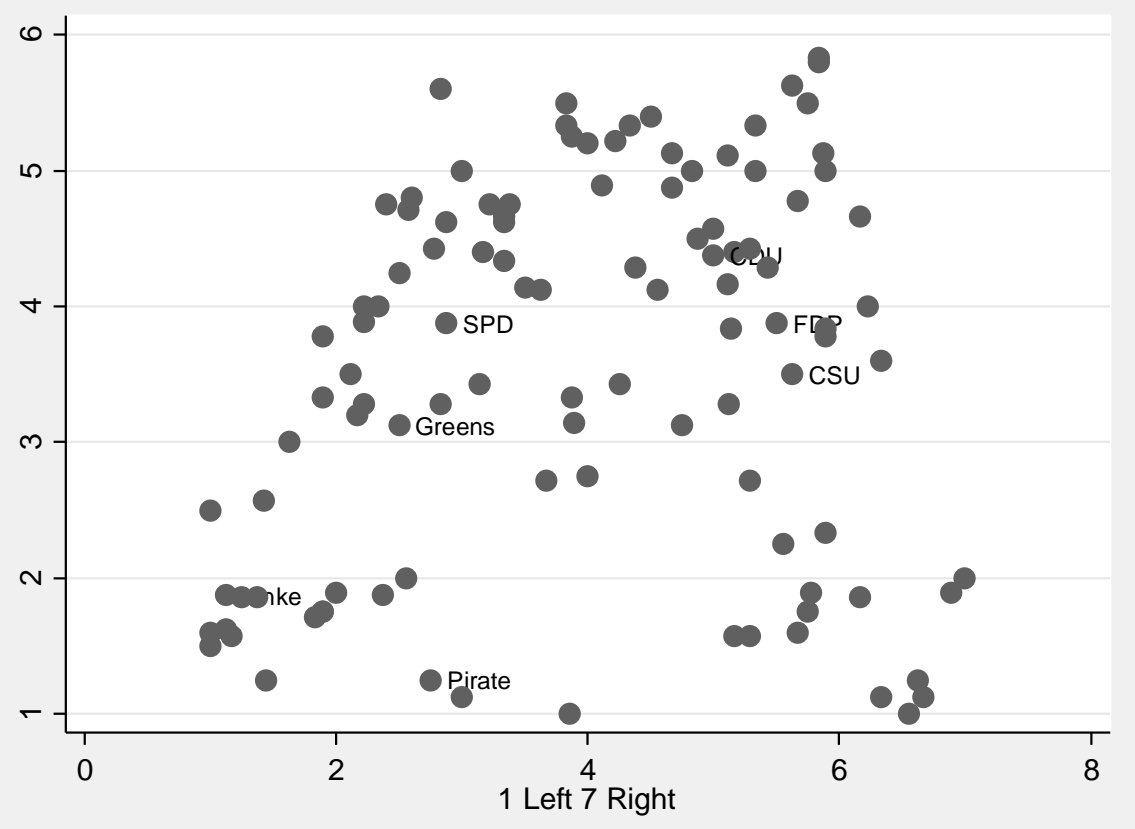


Note: Entries are mean ideology scores of parties on the x-axis (1-7); mean scores on the EU-principles indicator (3-21); and mean scores on the EU democracy indicator (1-7) in the bottom figure.

Figure 3: Comparing Changing Integration Stances of German parties to other WE parties:

EU Democracy:

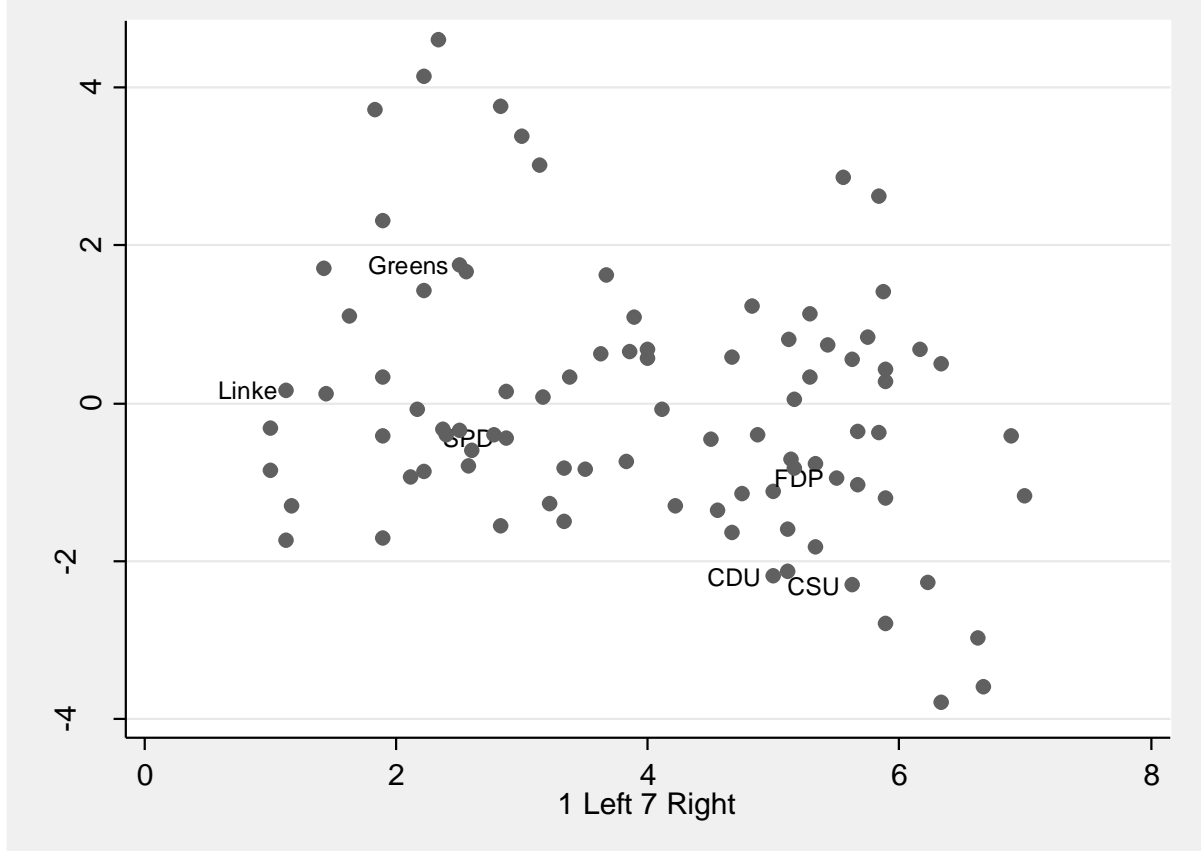

EU Performance:

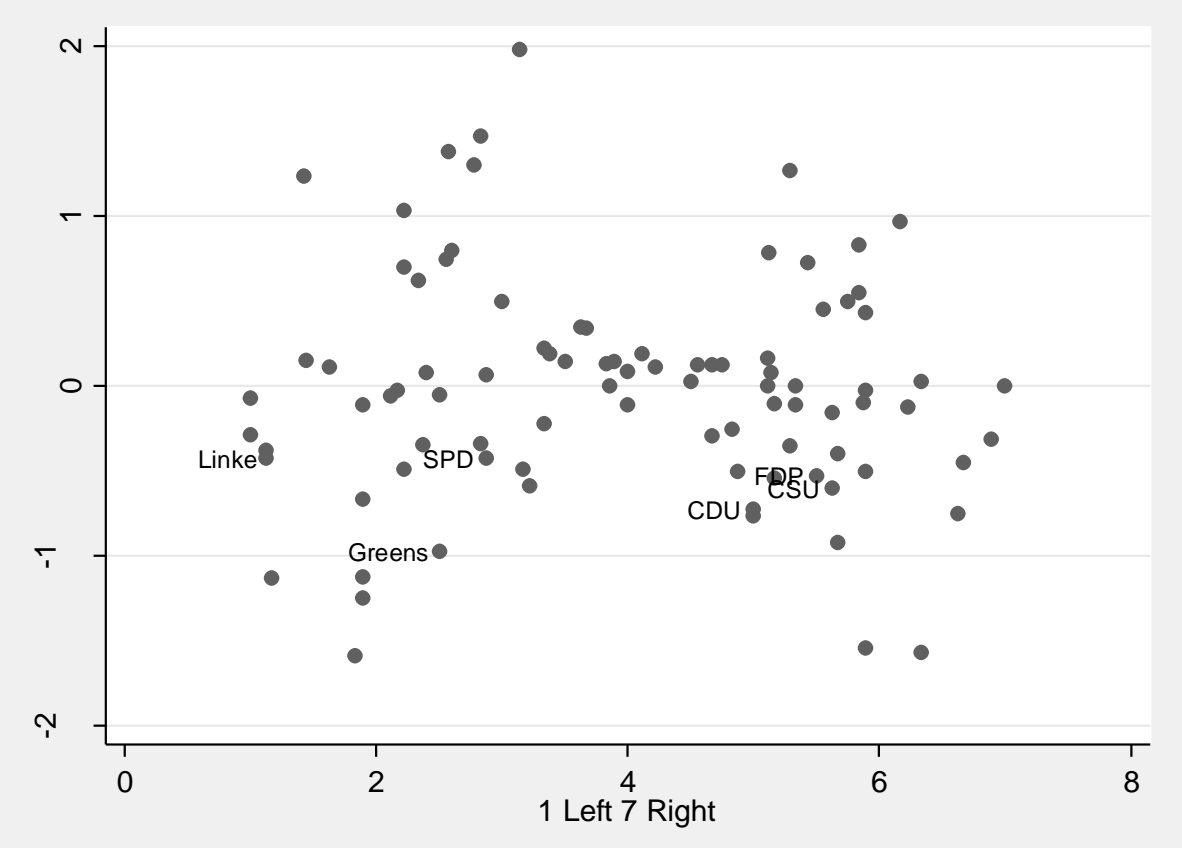


Note: Entries are mean ideology scores of parties on the x-axis (1-7); on the y-axis, mean change scores about EU-principles (top figure) and EU performance evaluations (bottom figure), with negative scores indicating a shift towards a critical view about the EU between 2008 and 2013. 
Figure 4: Comparing Changing Integration Stances of Governing Parties in Western Europe:

EU Principles:

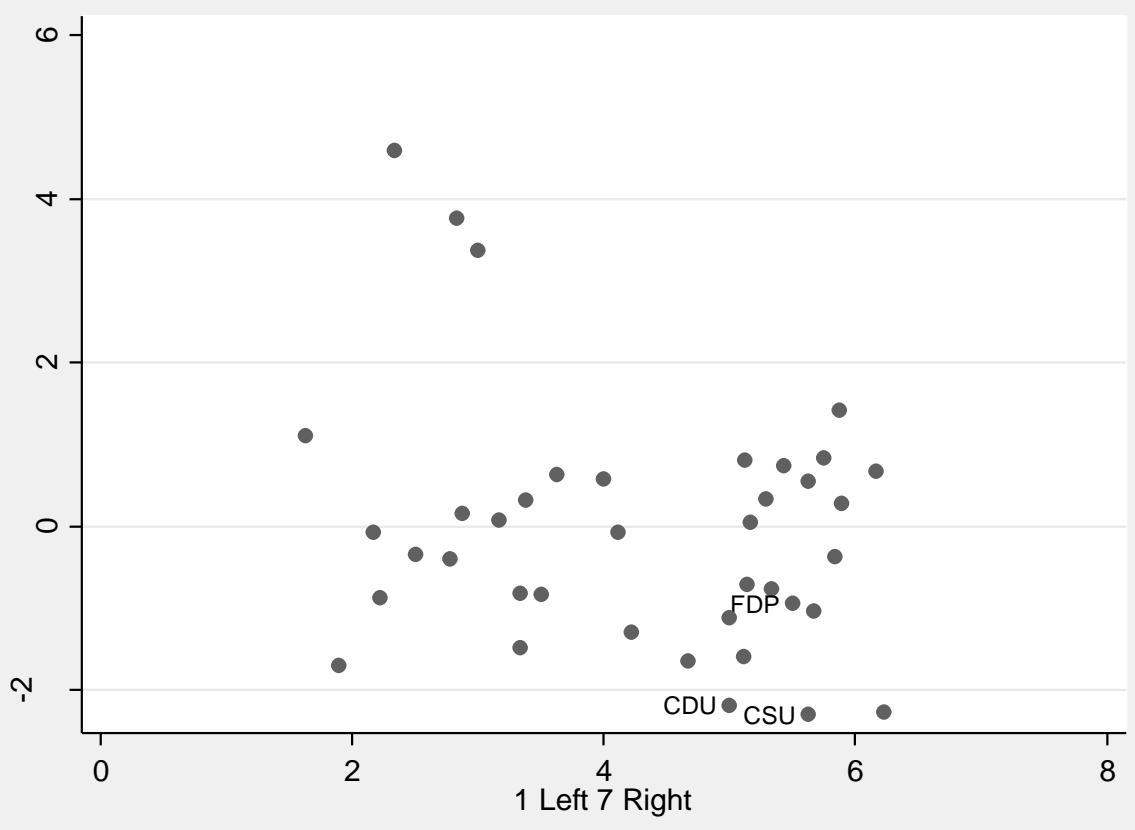

EU Democracy:

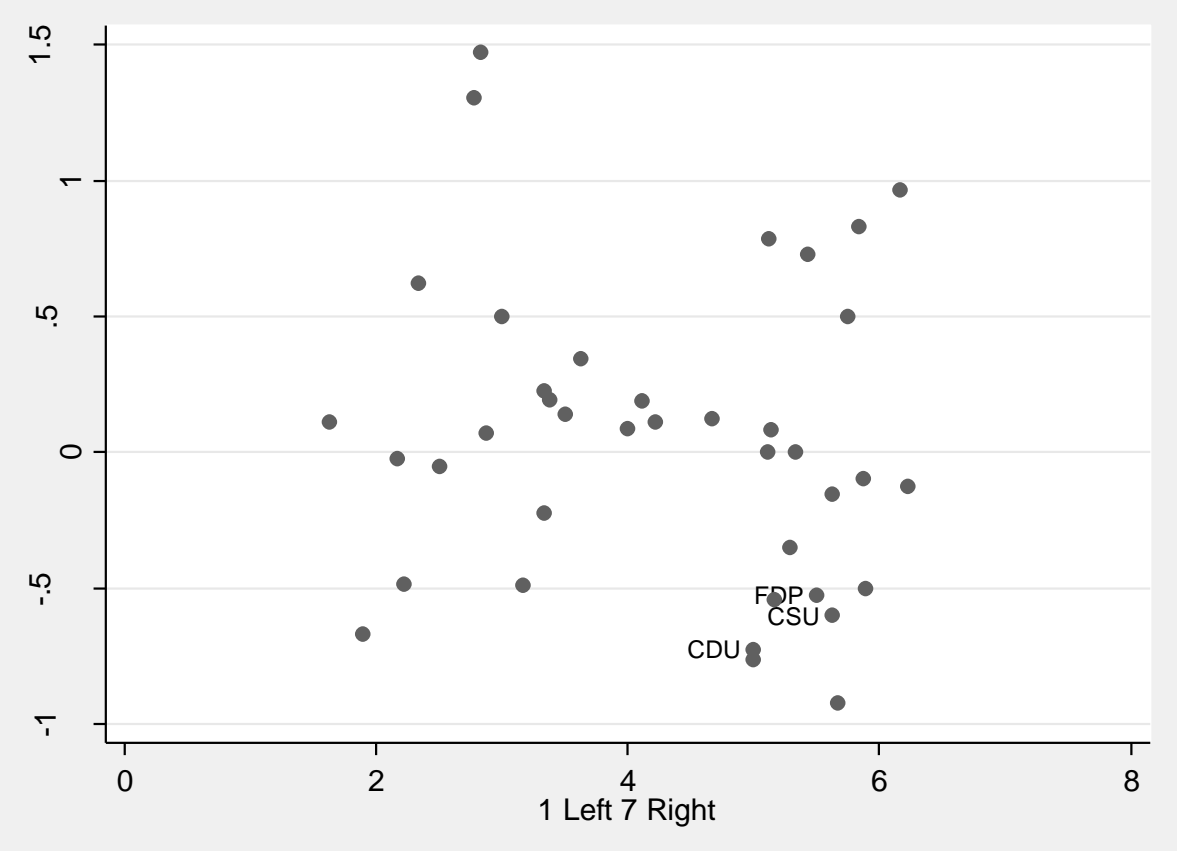

Note: Entries are mean ideology scores of parties on the $x$-axis (1-7); the $y$-axis displays change scores about EU-principles (top figure) and EU performance evaluations (bottom figure). Negative scores indicating a shift towards a critical view about the EU between 2008 and 2013. 